\title{
Sex-Steroid Formation in Gonadal Tissue Homogenates During the Testicular Cycle of the Redwinged Blackbird (Agelaius phoeniceus)
}

\author{
JOEL T. KERLAN, ${ }^{1}$ ROBERT B. JAFFE, ${ }^{2}$ AND ANITA H. PAYNE \\ Departments of Zoology and Obstetrics and Gynecology and The Steroid Research \\ Unit, Reproductive Endocrinology Program, University of Michigan, \\ Ann Arbor, Michigan 48104
}

Received May 1, 1973

\begin{abstract}
Fluctuations in the in vitro metabolism of pregnenolone- ${ }^{3} \mathrm{H}$ and progesterone ${ }^{-44} \mathrm{C}$ were studied in the testes of captive, photoinduced, adult Redwinged Blackbirds (Agelaius phoeniceus) during the gonadal cycle. Starting material utilization was high (87-99\%) during the photosensitive stage (breeding period), decreased during the regressive stage, and leveled off at about $40 \%$ in the refractory stage. The extent of testosterone synthesis varied in a bimodal pattern during the testicular cycle. Peaks in testosterone synthesis occurred during the photosensitive and regressive stages. However, testosterone formation was not detected in the refractory stage.

In addition to testosterone, 20 $\beta$-dihydropregnenolone $(3 \beta, 20 \beta$-dihydroxypregn5 -ene), $20 \alpha$-dihydropregnenolone $(3 \beta, 20 \alpha$-dihydroxypregn-5-ene), $20 \beta$-dihydroproges-

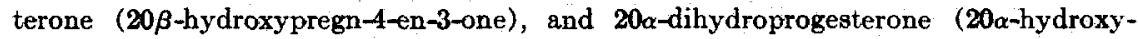
pregn-4-en-3-one) were isolated. The $20 \alpha$-pregnenols were detected only during the regressive and refractory stages. Moreover, an inverse relationship was seen between the formation of $20 \alpha$-pregnenols and testosterone in the photosensitive and refractory stages.

The physiological significance of a bimodal pattern of testosterone synthesis and of a restricted occurrence of $20 \alpha$-pregnenol formation in blackbirds is discussed in reference to the proposal by Lacy that two major populations of steroidogenic cells are present in the testis.
\end{abstract}

Initial studies of the in vitro production of testicular steroids in birds have revealed that the pathway of androgen synthesis and required cofactors are similar to those reported in mammals (Fevold and Eik-Nes, 1962, 1963; Fevold and Pfeiffer, 1968). In addition, bird testes are capable of de novo synthesis of testosterone from acetate (Connell et al., 1966). A major difference, howcver, is the elevated level of 4-pregnenol formation in birds compared to mammals (Fevold and Eik-Nes, 1963).

\footnotetext{
${ }^{1}$ Present address: Department of Biology, Hobart and William Smith Colleges, Geneva, New York 14456.

${ }^{2}$ Present address: Reproductive Endocrinology Center, Department of Obstetrics and Gynecology, University of California, San Francisco, San Francisco, California 94143.
}

In seasonal-breeding birds, testosterone formation has been shown to fluctuate with testis size. Fevold and Eik-Nes (1962) reported that $17 \alpha$-hydroxylase activity increases with increasing testis size in English Sparrows (Passer domesticus). More recently Cardinali et al. (1971) have shown that testosterone formation occurs during both the breeding and nonbreeding season in the domestic duck. These findings are consistent with reports that peaks in plasma testosterone concentration (Jallageas and Assenmacher, 1970; Garnier, 1971) and testicular vein plasma testosterone concentration (Garnier and Attal, 1970) occur during both seasons of the gonadal cycle in this species.

It is known that testosterone treatment can modify avian reproductive physiology. 
On the one hand, testosterone treatment can stimulate the completion of spermatogenesis, prevent post-breeding testicular regression, or induce testicular growth and restore spermatogenesis in atrophied gonads in certain species (reviewed by Lofts and Murton, 1973). On the other hand, testosterone treatment has been found to inhibit testicular and pituitary growth, reduce pituitary gonadotropin content, or antagonize the stimulatory effects of light on the cytology of gonadotropic cells in the pituitary (for recent reviews see Kordon and Gogan, 1970; Stetson, 1971; Tixier-Vidal and Follett, 1973).

The Redwinged Blackbird (Agelaius phoeniceus) is a seasonal-breeding species (Wright and Wright, 1944; Brenner, 1967; Payne, 1969; Kerlan, 1972). The testicular cycle consists of the photosensitive, regressive, and refractory stages. The photosensitive stage is associated with testicular growth and breeding activity. After the breeding season the gonads regress and in nature testicular regression is associated with photorefractoriness. Photorefractoriness is characterized by the failure of long day lengths to stimulate gonadal growth.

The present studies were undertaken to characterize the relationship between the extent of the in vitro production of testosterone, $20 \beta$-dihydropregnenolone

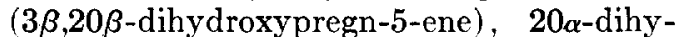
dropregnenolone $(3 \beta, 20 \alpha$-dihydroxypregn-

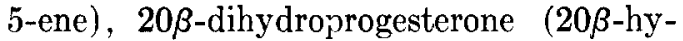
droxypregn-4-en-3-one) and $20 \alpha$-dihydroprogesterone $\quad(20 \alpha$-hydroxypregn-4-en-3one) and testis size during each stage of the photo-induced gonadal cycle.

\section{MATERIALS AND METHODS}

\section{Animals}

Adult male blackbirds were initially maintained in an outdoor aviary. Food (Purina Game Bird Chow-Finisher) mixed with mineralized grit and water were provided ad lib. Steroid formation in one bird ( $\mathrm{Rg}-696.3 \mathrm{mg}$; Table 3) that was continuously maintained in an outdoor aviary was measured. In the remaining studies, birds were transferred from the aviary to photoperiod rooms which provided $18 \mathrm{hr}$ light (0800-0200), $6 \mathrm{hr}$ dark
(LD 18:6) and were maintained at room temperature. To monitor changes in testis size, laparotomies were routinely performed on all birds before they were placed in the photoperiod rooms and on representative birds at selected intervals during this treatment. Birds were classified in the photosensitive stage if testicular size increased markedly between two observations. On the other hand, birds that were observed to pass through the photosensitive stage and then displayed a significant reduction in gonadal size were considered in the regressive stage. Since testes of minimal size are not found exclusively in the refractory stage, only birds whose gonads failed to enlarge after 1-mo exposure to a LD 18:6 regimen were considered to be refractory. In one experiment, birds that were continuously maintained on this long photoperiod from 15 July to 5 February remained photorefractory.

\section{Experimental Procedure}

Materials. Progesterone- $4{ }^{14} \mathrm{C}$, specific activity (sp act) $58.5 \mathrm{mCi} / \mathrm{mmole}$ and pregnenolone $-7{ }^{3} \mathrm{H}$, $\mathrm{sp}$ act $500 \mathrm{mCi} / \mathrm{mmole}$ were obtained from Amersham/Searle (Arlington Heights, IL). Prior to use, radiochemical homogeneity of the starting materials was established by submitting each steriod to two different paper-partition chromatography (PPC) systems and recrystallization of an aliquot with authentic progesterone or pregnenolone.

The following PPC systems were used to purify the products: System 1 heptane; formamide; System 2 heptane:benzene, formamide (1:1); System 3 heptane:methanol:water (5: 4:1); System 4 ligroin, propylene glycol; System 5 heptane:benzene:methanol:water (2:1:4:1); System 6 toluene, propylene glycol; System 7 cyclohexane:benzene, formamide $(1: 1)$.

PPC was performed on Whatman No. 1 paper. All organic solvents were redistilled. The melting point of all crystalline steroid standards was determined and each steroid was recrystallized prior to use.

Incubation procedures. Birds were decapitated and the testes were removed, measured, weighed, and placed in Krebs-Ringer bicarbonate buffer ( $\mathrm{pH}$ 7.4) which was kept on ice.

In the majority of experiments, both testes from an individual were used. In two trials during the regressive stage and in all trials during the refractory stage, however, testicular tissue was pooled from several birds to provide adequate material. All gonads were incubated within $\mathbf{4 5}$ min of their removal.

The testes were homogenized with a PotterElvehjem homogenizer in $1 \mathrm{ml}$ Krebs-Ringer 


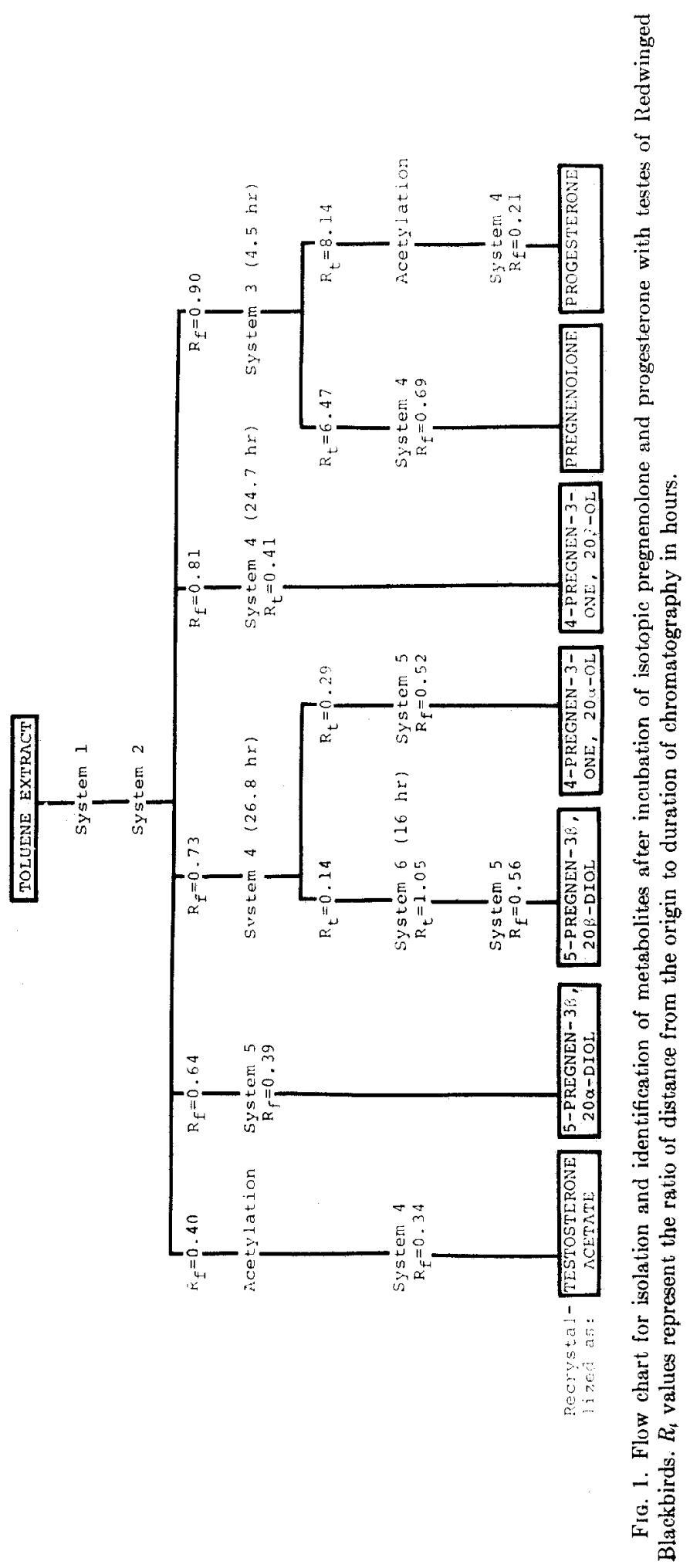


bicarbonate buffer containing $7 \mu$ moles NADP, $7 \mu$ moles NAD, $50 \mu$ moles $\mathrm{MgCl}_{2}, 150 \mu$ moles glucose-6-phosphate, and 1.6 units glucose-6-phosphate dehydrogenase (Sigma, St. Louis, MO) packed in ice. The homogenizer was rinsed with another milliliter of buffer. Each incubation beaker contained $0.017 \mu$ moles $(8.5 \mu \mathrm{Ci})$ of pregnenolone- $7-{ }^{3} \mathrm{H}$ and $0.017 \mu$ moles $(1.0 \mu \mathrm{Ci})$ of progesterone $-4-{ }^{14} \mathrm{C}$ in 2 drops of propylene glycol. All incubations were carried out for $3 \mathrm{hr}$ in a Dubnoff metabolic incubator at $41^{\circ}$ with $95 \%$ oxygen and $5 \% \mathrm{CO}_{2}$ as the gaseous phase. The reactions were terminated by adding diethyl ether-ethyl acetate $(4: 1, \mathrm{v} / \mathrm{v})$.

Tissueless controls were run simultaneously for cach experiment. Four representative controls were processed. Three of four controls contained tritiated and ${ }^{14} \mathrm{C}$-labeled material with chromatographic mobility similar to $20 \alpha$-dihydroprogesterone. Mean blank values were subtracted from all conversions reported in this study.

Extraction and chromatographic identification. Progesterone $(300 \mu \mathrm{g})$, testosterone $(300 \mu \mathrm{g})$, and in many experiments pregnenolone $(100 \mu \mathrm{g})$ were added prior to extraction of the reaction mixture. The extraction procedure used was that described by Fevold and Pfeiffer (1968) with minor modifications. Fight milliliters of water were added to the incubation flask and the resultant solution was extracted with $10 \mathrm{ml}$ of diethyl ether-ethyl acetate $(4: 1, v / v)$. This extract was mixed thoroughly, centrifuged, and the diethyl etherethyl acetate mixture was aspirated. The homogenate was extracted five times with the above mixture, and the fractions soluble in organic solvent ("free" fraction) were combined and evaporated in vacuo. The "free" fraction was partitioned between toluene and $\mathrm{NaOH}$ in a countercurrent fashion using two separatory funnels with four lower-phase transfers. The toluene fraction ("neutral" steroids) was washed with $\mathrm{H}_{2} \mathrm{O}$, evaporated in vacuo, and submitted to PPC in System 1 followed by PPC in System 2. The $\mathrm{NaOH}$ fraction ("phenolic") was not processed further. The metabolites in the neutral fraction that were identified in this study were subjected to chromatography as illustrated in Fig. 1.

Testosterone and progesterone were detected on paper chromatography by ultraviolet absorption. Pregnenolone was detected with phosphomolybdic acid (Neher, 1963). Isolation of the radioactive metabolites was completed after the radioactive material behaved similarly to steroid carrier in at least two different chromatography systems. Acetylation was performed at room temperature overnight using acetic anhydridepyridine $(1: 2, \mathrm{v} / \mathrm{v})$.
Fifty micrograms each of $20 \beta$-dihydropreg-

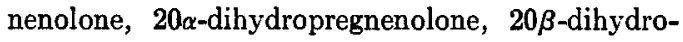
progesterone, and $20 \alpha$-dihydroprogesterone were added after the first chromatogram. The $\Delta^{4}-$ pregnenols were detected by ultraviolet absorption while the remaining two $\Delta^{3}$-pregnenols were detected with phosphomolybdic acid.

Recoveries of progesterone and testosterone acetate were measured in ethanol at $240 \mathrm{~nm}$, and pregnenolone was quantitated as described by Oertel and Eik-Nes (1959). Corrections were performed as described by Allen (1950).

Paper chromatograms were scanned with a Packard radiochromatogram scanner, Model 7200 , and radioactive samples were counted in a Packard Tri-Carb Scintillation Spectrometer, Model 3375 for sufficient time to assure a counting error no greater than 5\%. Appropriate quench corrections were performed using an internalstandard technique.

Establishment of radiochemical homogeneity. Varying amounts of authentic crystalline progesterone, pregnenolone, and testosterone acetate were added to aliquots from pools of each of these isolated radioactive steroids. They were successively recrystallized until constant $\mathrm{sp}$ act was achieved between crystals and mother liquors. Calculations of reported conversions for these steroids was based upon the amount of starting material added to the incubation beakers with appropriate corrections for recrystallization and recovery data. The identity of each pregnenol was assessed twice by recrystallization of representative samples from various experiments.

\section{RESULTS}

\section{Identification of Steroids}

A representative series of recrystallizations of pregnenolone, progesterone, and testosterone acetate is presented in Table 1. In addition, radiochemical homogeneity of the pregnenols from selected incubations is illustrated in Table 2. No significant decrease in specific activity of the pregnenols was noted in the initial recrystallization. The conversion to these steroids are minimal estimates, however, since they were not corrected for procedural losses.

\section{Starting-Material Utilization}

The extent of starting-material utilization varied during the testicular cycle (Table 3). In the photosensitive stage, the 
TABLE 1

Representative Recrystallization of Isolated Compounds During the Testicular Cyclea

\begin{tabular}{|c|c|c|c|c|c|c|c|}
\hline \multirow[b]{2}{*}{ Metabolite } & \multirow[b]{2}{*}{ Fraction } & \multicolumn{2}{|c|}{$\begin{array}{l}\text { Ps stage } \\
(\mathrm{dpm} / \mathrm{mg})\end{array}$} & \multicolumn{2}{|c|}{$\begin{array}{l}\text { Rg stage } \\
(\mathrm{dpm} / \mathrm{mg})\end{array}$} & \multicolumn{2}{|c|}{$\begin{array}{l}\text { Rf stage } \\
(\mathrm{dpm} / \mathrm{mg})\end{array}$} \\
\hline & & ${ }^{3} \mathrm{H}$ & ${ }^{14} \mathrm{C}$ & ${ }^{3} \mathrm{H}$ & ${ }^{14} \mathrm{C}$ & ${ }^{3} \mathrm{H}$ & ${ }^{14} \mathrm{C}$ \\
\hline \multirow[t]{4}{*}{ Pregnenolone } & SM & 4301 & 0 & 7321 & 0 & 7454 & 0 \\
\hline & $\mathrm{C}_{1}$ & 4296 & 0 & 7114 & 0 & 6984 & 0 \\
\hline & $\mathrm{C}_{2}$ & 4338 & 0 & 7233 & 0 & 6946 & 0 \\
\hline & $\mathrm{ML}^{b}$ & 4400 & 0 & 7372 & 0 & 7211 & 0 \\
\hline \multirow[t]{5}{*}{ Progesterone } & SM & 4557 & 2352 & 198 & 2430 & 1581 & 2428 \\
\hline & $\mathrm{C}_{1}$ & 4409 & 2311 & 160 & 2174 & 1443 & 2286 \\
\hline & $\mathrm{C}_{2}$ & 4414 & 2239 & 160 & 2156 & 1466 & 2238 \\
\hline & $\mathrm{C}_{3}$ & 4282 & 2230 & - & - & - & - \\
\hline & $\mathrm{ML}^{b}$ & 4287 & 2272 & 165 & 2182 & 1521 & 2232 \\
\hline \multirow[t]{5}{*}{ Testosterone acetate } & SM & 5086 & 547 & 21909 & 1453 & & \\
\hline & $\mathrm{C}_{1}$ & 4946 & 540 & 21566 & 1441 & & \\
\hline & $\mathrm{C}_{2}$ & 4863 & 527 & 20448 & 1321 & & \\
\hline & $\mathrm{C}_{3}$ & 4827 & 525 & 21043 & 1349 & & \\
\hline & $\mathrm{ML}^{b}$ & 5055 & 549 & 21909 & 1425 & & \\
\hline
\end{tabular}

a $\mathrm{P}_{\mathrm{S}}=$ photosensitive stage; $\mathrm{Rg}=$ regressive stage; $\mathrm{Rf}=$ refractory stage; $\mathrm{SM}=$ starting material; $\mathrm{C}=$ crystal.

${ }^{b} \mathrm{ML}=$ final mother liquor.

TABLE 2

Representative Recrystallization of Pregnenols ${ }^{a}$

\begin{tabular}{|c|c|c|c|c|}
\hline \multirow[b]{2}{*}{ Metabolite } & \multirow[b]{2}{*}{ Fraction } & \multicolumn{2}{|c|}{$\mathrm{dpm} / \mathrm{mg}$} & \multirow[b]{2}{*}{ Solvent system } \\
\hline & & ${ }^{3} \mathrm{H}$ & ${ }^{14} \mathrm{C}$ & \\
\hline \multirow[t]{4}{*}{ 20 $\beta$-Dihydropregnenolone } & SM & 11408 & 0 & \\
\hline & $\mathrm{C}_{1}$ & 11052 & 0 & Dichloromethane \\
\hline & $\mathrm{C}_{2}$ & 10965 & 0 & Ethanol-water \\
\hline & $\mathrm{ML}^{b}$ & 11586 & 0 & \\
\hline \multirow[t]{5}{*}{$20 \alpha$-Dihydropregnenolone } & SM & 895 & 0 & \\
\hline & $\mathrm{C}_{1}$ & 864 & 0 & Methanol \\
\hline & $\mathrm{C}_{2}$ & 893 & 0 & Ethanol-water \\
\hline & $\mathrm{C}_{3}$ & 895 & 0 & Dichloromethane \\
\hline & $\mathrm{ML}^{b}$ & 946 & 0 & \\
\hline \multirow[t]{4}{*}{ 20ß-Dihydroprogesterone } & SM & 1.349 & 1505 & \\
\hline & $\mathrm{C}_{1}$ & 1233 & 1533 & Hexane-acetone \\
\hline & $\mathrm{C}_{2}$ & 1222 & 1600 & Hexane-acetone \\
\hline & $M^{b}$ & 1259 & 1562 & \\
\hline \multirow[t]{4}{*}{$20 \alpha$-Dihydroprogesterone } & SM & 1700 & 1926 & \\
\hline & $\mathrm{C}_{1}$ & 1417 & 1845 & Hexane-acetone \\
\hline & $\mathrm{C}_{2}$ & 1459 & 1828 & Ethyl acetate \\
\hline & $\mathrm{ML}^{b}$ & 1438 & 1864 & \\
\hline
\end{tabular}

- See Table 1 for explanation of symbols. 
TABLE 3

Variations in the Metabolism of Starting Materials

\begin{tabular}{|c|c|c|c|c|c|}
\hline Stage $^{a}$ & $\begin{array}{l}\text { Total gonadal } \\
\text { weight } \\
\text { (mg) }\end{array}$ & $(N)^{c}$ & $\begin{array}{c}\% \\
\text { Pregnenolone-- }^{3} \mathrm{H} \\
\text { utilized }^{d}\end{array}$ & $\begin{array}{c}\% \\
\text { Progesterone-14 } \mathrm{C} \\
\text { utilized }\end{array}$ & $\frac{\text { Pregnenolone }}{\text { Progesterone }}$ \\
\hline \multirow[t]{3}{*}{ Ps } & 176.2 & (1) & 98.5 & 97.6 & 1.01 \\
\hline & 254.7 & (1) & 97.2 & 87.2 & 1.12 \\
\hline & 256.3 & (1) & 98.1 & 94.2 & 1.04 \\
\hline \multirow[t]{8}{*}{$\mathrm{Rg}$} & $696.3^{\mathrm{e}}$ & (1) & $\mathrm{nm}^{f}$ & $84 \cdot 3^{a}$ & nm \\
\hline & 562.4 & (1) & $\mathrm{nm}$ & 74.9 & $\mathrm{~nm}$ \\
\hline & 158.3 & (1) & $\mathrm{nm}$ & 74.8 & $\mathrm{~nm}$ \\
\hline & 73.8 & (1) & 41.2 & 71.9 & 0.57 \\
\hline & 22.5 & (1) & 48.8 & 63.8 & 0.77 \\
\hline & 18.1 & (1) & 62.0 & 85.7 & 0.73 \\
\hline & 17.1 & (2) & $\mathrm{nm}$ & 31.2 & $\mathrm{~nm}$ \\
\hline & 31.4 & (4) & 16.4 & 49.3 & 0.33 \\
\hline \multirow[t]{4}{*}{$\mathrm{Rf}$} & 25.8 & (5) & 30.8 & 44.1 & 0.70 \\
\hline & - & (5) & 30.3 & 54.2 & 0.56 \\
\hline & 22.9 & (6) & 40.4 & 51.8 & 0.78 \\
\hline & $21.8^{h}$ & (4) & $\mathrm{nm}$ & 25.1 & $\mathrm{~nm}$ \\
\hline
\end{tabular}

- $\mathrm{Ps}=$ photosensitive stage $; \mathrm{Rg}=$ regressive stage $\mathrm{Rf}=$ refractory stage.

- Total weight of tissue/incubation.

$c(N)=$ number of birds/incubation.

${ }^{d}$ Initial radionetivity - recovered radioactivity/initial radioactivity $\times 100$.

- Three hundred forty-five milligrams of tissue from a bird kept in an outdoor aviary was incubated.

$f \mathrm{~nm}=$ not measured.

- Initial amount of progesterone- ${ }^{14} \mathrm{C}$ was $0.53 \mu \mathrm{Ci}$.

${ }^{h}$ Refractory period extended about $27 \mathrm{wk}$ in birds maintained on a LD 18:6 regimen.

ratio of pregnenolone utilization to progesterone utilization was approximately one, but progesterone appeared to be preferentially utilized during the remainder of the cycle. Testes during the photosensitive stage metabolized nearly all of the pregnenolone and $87-98 \%$ of the progesterone. During the regressive stage, there was a general trend of decreasing utilization of the starting materials. It is important to note that during the refractory stage about $30-50 \%$ of the starting materials were metabolized. The extent of starting-material utilization by testes in the refractory stage was similar to that of minimal-size testes in the regressive stage. The lowest level of progesterone utilization was observed in testes from birds which remained in the refractory stage about $27 \mathrm{wk}$ on a lightdark 18:6 regimen. The level of progesterone utilization in these testes was approximately $50 \%$ less than in testes of birds in the refractory stage after only 1-mo exposure to the same photoperiod.

\section{Testosterone Formation}

The level of testosterone formation fluctuated dramatically and exhibited a bimodal pattern during the testicular cycle. If the level of testosterone production is expressed as dpm per bird (Table 4), the first peak occurred during the photosensitive stagc and was followed by a second peak during the regressive stage. Surprisingly, large testes in the regressive stage produced less testosterone than smaller testes in the regressive or photosensitive stages. In the refractory stage, testosterone was not detected.

If the level of testosterone formation is cxpresscd per unit weight of testicular tissue (Table 5), small testes during the regressive stage produced the most testosterone. Surprisingly, a small pair of testes 
TABLE 4

Variations in the in Vitro Production of Testosterone and Pregnenols During the Testicular Cycle:

\begin{tabular}{|c|c|c|c|c|c|c|c|c|c|c|}
\hline \multirow[b]{3}{*}{ Stage } & \multirow{3}{*}{$\begin{array}{c}\text { Total } \\
\text { gonadal } \\
\text { weight }^{a} \\
(\mathrm{mg})\end{array}$} & \multirow[b]{3}{*}{$(N)$} & \multicolumn{8}{|c|}{$\mathrm{dpm} \times 10^{-3} / \mathrm{bird}$} \\
\hline & & & \multicolumn{2}{|c|}{$\mathrm{T}^{b}$} & \multirow{2}{*}{$\frac{\begin{array}{c}20 \beta- \\
\mathrm{D} \Delta^{5} \mathrm{P}\end{array}}{{ }^{3} \mathrm{H}}$} & \multirow{2}{*}{$\begin{array}{c}20 \alpha- \\
\mathrm{D} \Delta^{5} \mathrm{P} \\
{ }^{3} \mathrm{H}\end{array}$} & \multicolumn{2}{|c|}{$20 \beta-\mathrm{DP}$} & \multicolumn{2}{|c|}{$20 \alpha-\mathrm{DP}$} \\
\hline & & & ${ }^{3} \mathrm{H}$ & ${ }^{14} \mathrm{C}$ & & & ${ }^{3} \mathrm{H}$ & ${ }^{14} \mathrm{C}$ & ${ }^{3} \mathrm{H}$ & ${ }^{14} \mathrm{C}$ \\
\hline \multirow[t]{3}{*}{ Ps } & 176.2 & (1) & 2493.7 & 271.2 & 260.1 & nf $c$ & 47.5 & 12.2 & nf & nf \\
\hline & 254.7 & (1) & 2728.2 & 308.8 & 146.9 & $\mathrm{nf}$ & 52.9 & 9.4 & nf & nf \\
\hline & 256.3 & (1) & 1127.5 & 130.1 & 220.6 & $\mathrm{nf}$ & 30.0 & 4.6 & nf & nf \\
\hline \multirow[t]{8}{*}{$\mathrm{Rg}$} & $696.3^{d}$ & (1) & 511.5 & 30.3 & 291.1 & 101.2 & 396.3 & 36.2 & $\mathrm{~nm}^{e}$ & $\mathrm{~nm}$ \\
\hline & 562.4 & (1) & 131.0 & 8.6 & 769.2 & 49.4 & 161.1 & 36.9 & 69.7 & 16.1 \\
\hline & 158.3 & (1) & 111.5 & 13.5 & $\mathrm{nf}$ & nf & 390.0 & 71.5 & 320.7 & 59.6 \\
\hline & 73.8 & (1) & 373.8 & 102.0 & $\mathrm{~nm}$ & $\mathrm{~nm}$ & $\mathrm{~nm}$ & $\mathrm{~nm}$ & $\mathrm{~nm}$ & $\mathrm{~nm}$ \\
\hline & 22.5 & (1) & 1568.1 & 225.6 & 167.5 & $\mathrm{nf}$ & 44.1 & 111.8 & $\mathrm{~nm}$ & $\mathrm{~nm}$ \\
\hline & 18.1 & (1) & 587.7 & 42.2 & nf & $\mathrm{nf}$ & 101.0 & 173.1 & $\mathrm{~nm}$ & $\mathrm{~nm}$ \\
\hline & 17.1 & (2) & 59.5 & 6.7 & $\mathrm{~nm}$ & $\mathrm{~nm}$ & 19.5 & 24.2 & 13.8 & 30.1 \\
\hline & 31.4 & (4) & 10.4 & 0.8 & 74.4 & 49.5 & 18.2 & 21.9 & 10.4 & 9.7 \\
\hline \multirow[t]{4}{*}{ Rf } & 25.8 & (5) & nf & nf & 213.6 & 119.4 & 16.1 & 23.0 & 23.3 & 24.0 \\
\hline & - & (5) & $n f^{\prime}$ & $\mathrm{nf}$ & 268.4 & 246.4 & 22.2 & 29.9 & 33.3 & 40.0 \\
\hline & 22.9 & (6) & $\mathrm{nf}$ & $\mathrm{nf}$ & 173.5 & 116.1 & 3.5 & 9.8 & 3.6 & 11.2 \\
\hline & $21.8^{\prime}$ & (4) & $\mathrm{nf}$ & $\mathrm{nf}$ & 68.3 & 81.8 & 4.6 & 5.1 & 6.1 & 6.2 \\
\hline
\end{tabular}

a Total weight of tissue in each incubation.

${ }^{b} \mathbf{T}=$ testosterone $; 20 \beta-\mathrm{D} \Delta^{5} \mathrm{P}=3 \beta, 20 \beta$-dihydroxypregn-5-ene; $20 \alpha-\mathrm{D} \Delta^{5} \mathrm{P}=3 \beta, 20 \alpha$-dihydroxypregn-5enc; $20 \beta$-DP $=20 \beta$-hydroxypregn-4-en-3-one; $20 \alpha$-DP $=20 \alpha$-hydroxypregn-4-en-3-onc. Corrected for losses.

- Not found.

$d$ Three hundred forty-five milligrams of tissue from a bird kept in an outdoor aviary was incubated in $8.5 \mu \mathrm{Ci}$ pregnenolone ${ }^{3} \mathrm{H}$ and $0.53 \mu \mathrm{Ci}$ progesterone- ${ }^{14} \mathrm{C}$.

- Not measured.

Extended refractory period.

$(22.5 \mathrm{mg})$ in the regressive stage produced the largest relative amount of testosterone observed in this study. A smaller elevation in testosterone production occurred earlier during the photosensitive stage. The occurrence of the major and minor increases in testosterone production during the testicular cycle, therefore, is variable and depends on whether an absolute or relative measurement is used.

\section{Pregnenol Formation}

Fluctuations in pregnenol production during the testicular cycle are also presented in Tables 4 and 5 . The level of $20 \beta$-dihydropregnenolone, expressed as dpm per bird (Table 4), was relatively stable, except for a transient elevation that was associated with large testes in the regressive stage. In contrast, the formation of $20 \beta$-dihydroprogesterone was variable. The level of synthesis of this steroid was minimal in the photosensitive stage, but increased to a peak during the regressive stage and then decreased as the testes reached minimal size in the regressive and refractory stages.

The level of 20 $\beta$-dihydropregnenolone, expressed as dpm per $100 \mathrm{mg}$ tissue (Table $5)$, was highest in the refractory stage whereas the formation of $20 \beta$-dihydroprogesterone was elevated in small testes during both the regressive and refractory stages. It is of interest to note that the production of $20 \alpha$-dihydropregnenolone and $20 \alpha$-dihydroprogesterone were sought but 
TABLE 5

Variations in the in Vitro Production of Testosterone and Pregnenols During the Testicular Cycle

\begin{tabular}{|c|c|c|c|c|c|c|c|c|c|c|}
\hline \multirow[b]{3}{*}{ Stage ${ }^{a}$} & \multirow{3}{*}{$\begin{array}{c}\text { Total } \\
\text { gonadal } \\
\text { weight } \\
(\mathrm{mg})\end{array}$} & \multirow[b]{3}{*}{$(N)^{c}$} & \multicolumn{8}{|c|}{$\mathrm{dmp} \times 10^{-3} / 100 \mathrm{mg}$} \\
\hline & & & \multicolumn{2}{|c|}{$\mathbf{T}^{d}$} & \multirow{2}{*}{$\frac{\begin{array}{c}20 \beta- \\
\mathrm{D} \Delta^{5} \mathrm{P}\end{array}}{{ }^{3} \mathrm{H}}$} & \multirow{2}{*}{$\begin{array}{c}\begin{array}{c}20 \alpha- \\
\mathrm{D} \Delta^{5} \mathrm{P}\end{array} \\
{ }^{3} \mathrm{H}\end{array}$} & \multicolumn{2}{|c|}{$20 \beta-\mathrm{DP}$} & \multicolumn{2}{|c|}{$20 \alpha-\mathrm{DP}$} \\
\hline & & & ${ }^{3} \mathrm{H}$ & ${ }^{14} \mathrm{C}$ & & & ${ }^{3} \mathrm{H}$ & ${ }^{14} \mathrm{C}$ & ${ }^{3} \mathrm{H}$ & ${ }^{14} \mathrm{C}$ \\
\hline \multirow[t]{3}{*}{ Ps } & 176.2 & (1) & 1415.3 & 153.9 & 147.6 & $\mathrm{nf}^{e}$ & 27.0 & 6.9 & $\mathrm{nf}$ & $\mathrm{nf}$ \\
\hline & 254.7 & (1) & 1071.1 & 121.2 & 57.7 & $\mathrm{nf}$ & 20.8 & 3.7 & $\mathrm{nf}$ & $\mathrm{nf}$ \\
\hline & 256.3 & (1) & 439.9 & 50.8 & 86.1 & $\mathrm{nf}$ & 11.7 & 1.8 & $\mathrm{nf}$ & $\mathrm{nf}$ \\
\hline \multirow[t]{8}{*}{$\mathrm{Rg}$} & $696.3^{\prime}$ & (1) & 73.5 & 4.4 & 41.8 & 14.5 & 56.9 & 5.2 & $\mathrm{~nm}^{g}$ & $\mathrm{~nm}$ \\
\hline & 562.4 & (1) & 23.3 & 1.5 & 136.8 & 8.8 & 28.7 & 6.6 & 12.4 & 2.9 \\
\hline & 158.3 & (1) & 70.4 & 8.5 & $\mathrm{nf}$ & $\mathrm{nf}$ & 246.4 & 45.2 & 202.6 & 37.7 \\
\hline & 73.8 & (1) & 508.4 & 138.7 & $\mathrm{~nm}$ & $\mathrm{~nm}$ & $\mathbf{n m}$ & $\mathrm{nm}$ & $\mathrm{nm}$ & $\mathrm{nm}$ \\
\hline & 22.5 & (1) & 6962.4 & 1001.7 & 743.7 & $\mathrm{nf}$ & 195.8 & 494.4 & $\mathrm{~nm}$ & $\mathrm{~nm}$ \\
\hline & 18.1 & (1) & 3244.1 & 232.9 & $\mathrm{nf}$ & $\mathrm{nf}$ & 557.5 & 955.5 & $\mathrm{~nm}$ & $\mathrm{~nm}$ \\
\hline & 17.1 & (2) & 695.6 & 78.3 & $\mathrm{~nm}$ & $\mathrm{~nm}$ & 228.2 & 282.6 & 160.9 & 352.2 \\
\hline & 31.4 & (4) & 132.5 & 9.9 & 949.3 & 631.0 & 232.2 & 279.8 & 131.1 & 123.8 \\
\hline \multirow[t]{3}{*}{$\mathrm{Rf}$} & 25.8 & (5) & $\mathrm{nf}$ & $\mathrm{nf}$ & 4143.1 & 2316.4 & 311.6 & 446.2 & 452.4 & 465.6 \\
\hline & 22.9 & (6) & $\mathrm{nf}$ & $\mathrm{nf}$ & 4549.2 & 3045.5 & 92.2 & 256.5 & 95.3 & 292.4 \\
\hline & $21.8^{h}$ & (4) & $\mathrm{nf}$ & nf & 1253.5 & 1500.9 & 84.0 & 893.6 & 111.5 & 113.4 \\
\hline \multicolumn{11}{|c|}{$\begin{array}{l}{ }^{a} \text { Ps = photosensitive st } \\
{ }^{b} \text { Total weight of tissue/ } \\
{ }^{c} \text { Number of birds/incub } \\
\text { ' Corrected for losses. } \\
\text { ' Not found. } \\
\text { s Three hundred forty-fil }\end{array}$} \\
\hline
\end{tabular}

not found in the photosensitive stage. Moreover, $20 \beta$-reductase activity exceeded $20 \alpha$-reductase activity throughout the photosensitive and regressive stages.

A comparison between the extent of pregnenol production and testosterone formation during the testicular cycle reveals that there was no apparent relationship between the production of $20 \beta$-pregnenols and testosterone. However, if the photosensitive stage is compared to the refractory stage, an inverse relationship existed between the synthesis of $20 \alpha$-pregnenols and testosterone. In the photosensitive stage, $20 \alpha$-pregnenols were absent, but large amounts of testosterone were produced. This relationship was reversed during the refractory stage.
Table 6 compares the percentage of the starting materials converted to the pregnenols during the photosensitive and refractory stages. The percentage of metabolized starting material converted to each steroid was calculated using the ratio of the radioactivity of each steroid divided by the difference of the radioactivity associated with the starting materials before and after the incubation. In the photosensitive stage, most of the starting materials were metabolized and the most abundant product was testosterone. However, the sum of the percentages of metabolized starting material converted to pregnenols per incubation accounted for only $1.1-1.7 \%$ of the pregnenolone ${ }^{3} \mathrm{H}$ and 0.2 $0.6 \%$ of the progesterone $-{ }^{14} \mathrm{C}$. In contrast, 
TABLE 6

Comparison of the Percentage of Starting Materials Converted to Pregnenols

\begin{tabular}{|c|c|c|c|c|c|c|c|c|}
\hline \multirow[b]{3}{*}{ Stage } & \multirow{3}{*}{$\begin{array}{c}\text { Total } \\
\text { gonadal } \\
\text { weightb } \\
\text { (mg) }\end{array}$} & \multirow[b]{3}{*}{$(N)^{c}$} & \multicolumn{6}{|c|}{ Percentage of metabolized starting materials } \\
\hline & & & \multirow{2}{*}{$\frac{20 \beta-\mathrm{D} \Delta^{5} \mathrm{P}}{{ }^{3} \mathrm{H}}$} & \multirow{2}{*}{$\frac{20 \alpha-\mathrm{D} \Delta^{5} \mathrm{P}}{{ }^{3} \mathrm{H}}$} & \multicolumn{2}{|c|}{$20 \beta-\mathrm{DP}$} & \multicolumn{2}{|c|}{$20 \alpha-\mathrm{DP}$} \\
\hline & & & & & ${ }^{2} \mathrm{H}$ & ${ }^{4} \mathrm{C}$ & ${ }^{2} \mathrm{H}$ & ${ }^{11} \mathrm{C}$ \\
\hline \multirow[t]{3}{*}{ Ps } & 176.2 & (1) & 1.4 & $n f^{d}$ & 0.3 & 0.6 & $\mathrm{nf}$ & nf \\
\hline & 254.7 & (1) & 0.8 & nf & 0.3 & 0.2 & nf & nf \\
\hline & 256.3 & (1) & 1.2 & nf & 0.2 & 0.2 & nf & nf \\
\hline \multirow[t]{3}{*}{ Rf } & 25.8 & (5) & 18.5 & 10.4 & 1.4 & 11.9 & 2.0 & 10.5 \\
\hline & - & (5) & 23.6 & 21.7 & 1.9 & 12.5 & 2.9 & 15.3 \\
\hline & 22.9 & (6) & 13.8 & 9.3 & 0.3 & 5.2 & 0.3 & 4.4 \\
\hline
\end{tabular}

${ }^{a} \mathrm{Ps}=$ photosensitive stage; $\mathrm{Rf}=$ refractory stage.

S Total weight of tissue/incubation.

- Number of birds/incubation.

Not found.

the decrease in the extent of starting material metabolism during the refractory stage was correlated with a marked increase in the production of these pregnenols. The sum of the percentages of metabolized starting material converted to these steroids per incubation accounted for 23.7-50.1\% of the pregnenolone- ${ }^{3} \mathrm{H}$ and $9.6-27.8 \%$ of the progesterone- ${ }^{14} \mathrm{C}$.

\section{DISCUSSION}

Utilization of pregnenolone and progesterone in steroid biosynthesis occurs during each stage of the gonadal cycle. There is a general trend of decreased starting material utilization during the regressive and refractory stages compared to the photosensitive stage. These findings imply that qualitative as well as quantitative changes in steroidogenesis are probably associated with variations in testicular size and histology during the annual gonadal cycle.

Testosterone formation in Redwinged Blackbird testes agrees with earlier studies of other avian species (Fevold and EikNes, 1962, 1963; Connell et al., 1966; Fevold and Pfeiffer, 1968; Nugara and Edwards, 1970; Cardinali and Rosner, 1971; Cardinali et al., 1971; Nakamura and Tanabe, 1972; Galli et al., 1973). Moreover, testosterone has been isolated from extracts of Redwinged Blackbird testes (Höhn and Cheng, 1967). The syn- thesis of testosterone from pregnenolone and progesterone in blackbird testes appears to fluctuate in a bimodal pattern during the testicular cycle. One rise is associated with intermediate size testes in the photosensitive stage. It is surprising to find a second rise associated with small testes in the regressive stage. Testosterone formation was not found in the refractory stage.

A second rise in testosterone formation during the nonbreeding period has also been reported in the domestic duck (Cardinali et al., 1971). In this species, testosterone formation in the nonbreeding period is about double that in the breeding period. In both ducks, and Redwinged Blackbirds, the level of testosterone formation, expressed on the basis of testis weight, is higher during the nonbreeding period. However, in both species the extent of testosterone synthesis, expressed per bird, is higher during the breeding period.

The functional significance of elevated testosterone formation during the photosensitive stage may involve a stimulatory effect of testosterone on spermatogenesis whereas testosterone produced during the regressive stage may act through a negative feedback mechanism to inhibit the hypothalamo-pituitary axis (Lofts and Murton, 1973). However, Farner (1967) and Stetson and Erickson (1971) have suggested that 
the onset of testicular regression may be regulated entirely by negative pituitary gonadotropin feedback. In contrast, testicular growth may be regulated by negative steroid feedback from the testes (Farner et al., 1968).

In addition to testosterone, four preg-

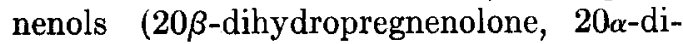
hydropregnenolone, $20 \beta$-dihydroprogesterone, $20 \alpha$-dihydroprogesterone) were formed by Redwinged Blackbird testes. The synthesis of $20 \beta$ - and $20 \alpha$-dihydropregnenolone is the first demonstration of their formation by avian testes. On the other hand, formation of $20 \beta$-dihydroprogesterone has been identified in the testes of English Sparrows (Fevold and Eik-Nes, 1962, 1963) roosters (Galli et al., 1973), and chick embryos (Galli and Wassermann, 1972, 1973) and production of the $20 \alpha$-isomer was reported in the above species and domestic duck (Cardinali and Rosner, 1971; Cardinali et al., 1971). Moreover, 20ß-dihydroprogesterone was found in an extract of cockrel testes (Delrio et al., 1967). It is noteworthy that in Redwinged Blackbirds $20 \beta$-reductase activity is equal to or greater than $20 \alpha$-reductase activity. A similar relationship exists in English Sparrow (Fevold and Fik-Nes, 1962, 1963) and chick embryo testes (Galli and Wassermann, 1972, 1973). In mammals, however, 20 $\alpha$-reductase activity is higher (Tamaoki et al., 1969).

The formation of $20 \alpha$-pregnenols by Redwinged Blackbird testes only during the regressive and refractory stage of the gonadal cycle raises the possibility that their synthesis is independent of gonadotropin control. This assumption is consistent with the observation that only hypophysectomized pigeons with atrophied and lipoidal seminiferous tubules contain a progestin-like steroid in the testes and the blood (Lofts and Marshall, 1959).

In the Redwinged Blackbirds an inverse relationship occurs between the extent of $20 \alpha$-pregnenol and testosterone formation. In the photosensitive stage, $20 \alpha$-pregnenols are not found but testosterone is produced in large amounts. This relationship is reversed during the refractory stage. An inverse relationship between the extent of
$20 \alpha$-pregnenol and testosterone formation also occurs in the domestic duck, but both steroids are found throughout the testicular cycle (Cardinali et al., 1971).

The inverse relationship between the level of 20x-pregnenol and testosterone formation in blackbird testes may be produced by $20 k$-pregnenol inhibition of testosterone production. Recent studies in mammals have shown that 20o-dihydroprogesterone is a potent inhibitor of $\mathrm{C}_{17^{-}}$$\mathrm{C}_{20}$ lyase, a side-chain-cleaving enzyme in the pathway of testosterone synthesis (Neher and Kahnt, 1965; Shikita et al., 1967; Tamaoki et al., 1969). Although similar studies have not been performed in birds, it is noteworthy that the addition of $17 \alpha, 20 \alpha$-dihydroxy-4-pregnen-3-one reduces conversion of progesterone to testosterone about 50\% in English Sparrow testes (Fevold and Eik-Nes, 1963).

Discovery of a bimodal pattern of testosterone formation and the restricted occurrence of pregnenol synthesis in blackbirds is consistent with the concept proposed by Lacy $(1967,1969)$ of two populations of steroidogenic cells in the testis. These populations, located in the interstitium and seminiferous tubules can probably be distinguished by differences in steroid biosynthesis. In rats, the extent of $20 \alpha$-dihydroprogesterone formation is greater in the seminiferous tubules than in the interstitium (Lacy et al., 1969). Moreover, heat treatment of rat testes only increased $20 \alpha$-dihydroprogesterone production in the seminiferous tubules. This elevation was associated with a dramatic increase in the amount of lipid and cholesterol visualized by histochemical techniques (Lacy and Pettitt, 1970). It is of interest that seasonal changes in testicular histochemistry of Redwinged Blackbirds (Pavne, 1969) and many other avian species (reviewed by Lofts and Murton, 1973) involve a shift in the location of sudanophilic material from the interstitium during the photosensitive stage to the seminiferous tubules in the regressive and refractory stages.

This shift in sudanophilic material in bird testes may reflect a change in the site 
of steroid formation. Moreover, it remains to be established whether this change is associated with a transition from androgen synthesis to pregnenol formation during the testicular cycle of Redwinged Blackbirds.

\section{ACKNOWLEDGMENTS}

We thank Professor B. E. Frye for his critical evaluation of these data. We also thank Jahn Seubert, Brooke Meanley, and Mildred Miskimen of the Bureau of Sport Fisheries and Wildlife for the supply of blackbirds.

\section{REFERENCES}

$\Lambda$ LLEN, W. M. (1950). $\Lambda$ simple method for analyzing complicated absorption curves, of use in the colorimetric determination of urinary steroids. J. Clin. Endocrinol. 10, 71-83.

Brenner, F. J. (1967). Seasonal correlations of reserve energy of the Redwinged Blackbird. Bird-Banding 38, 195-211.

Cardinali, D. P., Cuelio, A. E., Tramezzani, J. H., AND RosNer, J. M. (1971). Effects of pinealectomy on the testicular function of the adult male duck. Endocrinology 89, 1082-1093.

Cardinali, D. P., and Rosner, J. M. (1971). Effects of melatonin serotonin and $N$-acetylserotonin on the population of steroids by duck testicular homogenates. Steriods 18, 25-37.

Connell, G. M., Connell, C. J., and Eik-Nes, K. B. (1966). Testosterone synthesis by the two-day-old chick testis in vitro. Gen. Comp. Endocrinol. 7, 158-165.

Delrio, G., Lupo, di Prisco, C., and Chieffi, G. (1967). Steroid hormones in the testicular tissue of Gallus domesticus. Experientia 23, 594.

FarNer, D. S. (1967). The control of avian reproductive eycles. Proc. Int. Ornithol. Congr. 14th, pp. 107-133.

Farner, D. S., Morton, M. L., and Follett, B. K. (1968). The limitation of rate of photoperiodically induced testicular growth in the Whitecrowned Sparrow Zonotrichia leucophrys gambelii. The effect of hemicastration. Arch. Anat. Histol. Embryol. 51, 190-196.

Fevold, H. R., ANd Eik-Nes, K. B. (1962). Progestcronc metabolism by tcsticular tissuc of the English Sparrow (Passer domesticus) during the annual reproductive eycle. Gen. Comp. Endocrinol. 2, 506-515.

Fevold, H. R., AND Erk-Nes, K. B. (1963). Progesterone metabolism by testicular tissue of the English Sparrow (Passer domesticus). Gen. Comp. Endocrinol. 3, 335-345.

Fevold, H. R., and Preiffer, E. W. (1968). Androgen production in vitro by Phalarope gonadal tissue homogenates. Gen. Comp. Endocrinol. 10, 26-33.

Galdi, F. E., and Wassermann, G. F. (1972). Steroid biosynthesis by testes and ovaries of 15-day-old chick embryos. Gen. Comp. Endocrinol. 19, 509-514.

Galli, F. E., and Wassermann, G. F. (1973). Steroid biosynthesis by gonads of 7 - and 10 day-old ehick embryos. Gen. Comp. Endocrinol. 21, 77-83.

Galli, F. E., Irusta, O., and Wassermann, G. F. (1973). Androgen production by testes of Gallus domesticus during postembryonic development. Gen. Comp. Endocrinol. 21, 262-266.

GaRnier, D. H. (1971). Variations de la testosterone du plasma périphérique chez le Canard Pékin au cours du cycle annual. C.R. Acad. Sci. (Paris) 272, 1665-1668.

Garnier, D. II., AND Atral, J. (1970). Variations de la testosterone du plasma testiculaire et des cellules interstitielles chez le Canard Pekin au cours du cycle annual. C. R. Acad. Sci. (Paris) 270, 2472-2475.

Höhn, E. O., ANd Cheng, S. C. (1967). Gonadal steroid hormones in Wilson's phalaropes (Steganopus tricolor) and other birds in relation to plumage and sex behavior. Gen. Comp. Endocrinol. 8, 1-11.

Jallageas, M., and Assenmacher, I. (1970). Testostéronémie du Canard photostimulé ou soumis á injections répétées de testostérone. C. R. Soc. Biol. Fil. 164, 2338-2341.

KrRLAN, J. T. (1972). The testicular cycle in adult captive Redwinged Blackbirds (Agelaius phoeniceus): A comparison of changes in testis size, testosterone and 20-hydroxyprogestin formation, and mouth lining color. Doctoral Dissertation. University of Michigan.

Kordon. C., AND Gogan, F. (1970). Interaction du feed-back et de la photostimulation dans les regulations gonadotropes chez les mammiféres et les oiseaux. In "La Photoregulation de la Reproduction chez les Oiseaux et les Mammiferes" (J. Benoit et I. Assenmacher, eds.), pp. 325-350. Coll. Int. C.N.R.S. No. 172, Paris. LACY, D. (1967). The seminiferous tubules in mammals. Endeavour 26, 101-108.

Lacy, D., Vinson, G. P., Coldins, P., Bell, J., Fryson, P., Pudnex, J., and Pettitt, A. J. (1969). The Sertoli cell and spermato-genesis in mammals. In "Progress in Endocrinology" (C. Gual, ed.), pp. 1019-1029. Excerpta Medica Foundation, Amsterdam.

Lacy, D., and Petritr, A. J. (1970). Sites of hormone production in the mammalian testis and their significance in the control of male fertility. Brit. Med. Bull. 26, 87-91. 
Lofts, B., And Marshall, A. J. (1959). The postnuptial occurrence of progestins in the seminiferous tubules of birds. J. Endocrinol. 19, 16-21.

Lofts, B., ANd Murton, R. K. (1973). Reproduction in birds. In "Avian Biology" (D. S. Farner and J. R. King, eds.), Vol. 3, pp. 1-109. Academic Press, New York.

Nakamura, T., and Tanabe, Y. (1972). In vitro steroidogenesis by testes of the chicken (Gallus domesticus). Gen. Comp. Endocrinol. 19, 432440.

NeHER, R. (1963). Chromatographic mobilites. In "Physical Properties of the Steroid Hormones" (L. L. Engel, ed.), pp. 37-68. Macmillan, New York.

Neher, R., ANd Kahnt, F. W. (1965). On the biosynthesis of testicular steroids in vitro and its inhibition. Experientia 21, 310-312.

Nugara, D., AND Edwards, H. M. (1970). In vitro androgen metrbolism by fat-deficient cockrel testes and uropygial gland. J. Nutr. 100, 539544.

Oertel, G. W., and Elk-Nes, K. B. (1959). Determination of $\Delta^{5}$-3-beta-hydroxysteroids. Anal. Chem. 31, 98-100.
Payne, R. B. (1969). Breeding seasons and reproductive physiology of Tricolored Blackbirds and Redwinged Blackbirds. Univ. California Publ. Zool. 90, 1-137.

Shikita, M., Inano, H., and Tamaoki, B. (1967). Further studies of $20 \alpha$-hydroxysteroid dehydrogenase of rat testes. Biochemistry 6, 1760-1764.

Stetson, M. H. (1971). Control mechanisms in the avian hypothalamo-hypophysial axis. Doctoral Dissertation. University of Washington, Seattle.

Stetson, M. H., and Erickson, J. E. (1971). Endocrine effects of castration in Whitecrowned Sparrows. Gen. Comp. Endocinol. 17, 105-114.

Tamaoki, B., Inano, H., and Nakano, H. (1969). In vitro synthesis and conversion of androgens in testicular tissue. In "The Gonads" (K. W. McKerns, ed.), pp. 547-613. Appleton-CenturyCrofts, New York.

Tixier-Vidal, A., and Follett, B. K. (1973). The adenohypophysis. In "Avian Biology" (D. S. Farner and J. R. King, eds.), Vol. 3, pp. 110183. Academic Press, New York.

Wright, P. L., and Wright, M. H. (1944). The reproductive cycle of the male Redwinged Blackbird. Condor 46, 45-59. 